\title{
KIRKPATRICK MODEL EVALUATION ON THE IMPLEMENTATION OF STRENGTHENING SCHOOL SUPERVISORS BASED ON BEST PRACTICE, HOTS AND ADULT LEARNING
}

\author{
Renny Yunus, Nirva Diana, Siti Patimah, Agus Pahrudin \\ Raden Intan State Islamic University, Lampung \\ rennyyunus@gmail.com \\ nirvadiana@radenintan.ac.id \\ sitipatimah@ radenintan.ac.id \\ agus.pahruddin@radenintan.ac.id
}

\begin{abstract}
Evaluation is a process or activity of selecting, collecting, analyzing and presenting information that can be used as a basis for decision making and for the preparation of further programs. Petronila Jean describes that education and training is the method of technical and vocational education and training which is appreciated as an effort to acquire practical skills, attitudes, understanding and being able to process them in Best Practice and generate an idea or idea about a technique, method, process, activity. , intensive so as to provide them with new knowledge and implications. This study aims to analyze and find outResult Evaluation on the implementation of training to strengthen school supervisors based on Best Practice, HOTS and adult learning. This research method uses qualitative methods with a sample of 100 school supervisors. The data in this study were collected using a questionnaire and reliability testing was carried out with Cronbach Alpha. The results of the study describe the Kirkpatrick Evaluation Model in the Training Program for strengthening school supervisorsThe results of the learning outcomes of the training participants have increased and the difference is significant, it's just that when viewed from each aspect, namely aspects of knowledge, understanding and application, that the results obtained have increased but the results of the differences and the improvements are not significant.
\end{abstract}

Keywords: Kirkpatrick's Model, Evaluation, Training

\section{A. INTRODUCTION}

Improving the quality of education is a shared responsibility involving various groups, from structural aspects ranging from the central level (Ministry) to education units.(Notoatmojo 2003: 60) National Education System Law No. 20 of 2003 about the National Education System Article 39 paragraph 1 states that the education agency is in charge of carrying out administration, management, development, supervision and technical services to support the educational process in the education unit. other than thatEducation staff too is an integral part of school activities whose function is to provide services in order to achieve the goals of education in schools. Education is a crucial field in the progress of the 
nation and the State.Based on Human Development Index (HDI) data, in 2018 Indonesia experienced an increase of 0.82 percent to 71.39 which was in the middle rank. However, this achievement is still lower than countries in the same region, such as Singapore, Malaysia and Brunei Darussalam, which have the category of very high human development. Of course, the HDI is lowis a serious matter that must immediately receive urgent attention, especially in the millennial era which is full of competition.

KThe work of school supervisors has received strong attention and the quality of their educational institutions has not been improved and has even decreased in the past 2 years. This is inversely proportional to the general goals and specific objectives of the education and training program for School Supervisors in Indonesia based on Permendiknas No 12 of 2007, having the main task in terms of Academic Supervision, Managerial Supervision, Educational Evaluation, Research and Sustainable Development. Given its role and function, various efforts to develop School Supervisors have been carried out by the SubDirectorate for Career Development and Performance Appraisal, Directorate of Development, Directorate General of Teachers and Education Personnel, Ministry of Education and Culture.At a minimum, in order to achieve the 2015-2019 RPJMN-Renstra GTK target, the Ministry of Education has determined the Average Achievement Target of Knowledge and Skills of Education Personnel in the 2015-2019 GTK Renstra

School supervisors hold the highest career positions who should be responsible for the advancement of education in Indonesia. It is not surprising that education data shows an alarming number for supervisors even though they have participated in education and training programs with the aim of helping to improve the ability of employees to carry out their current duties, while education is more oriented towards increasing the ability to carry out new tasks which are in the future. Meanwhile, training or training is part of the educational process, which aims to improve the special abilities and skills of a person or group of people.(Sutrisno 2015: 54)Training is related to increasing the ability or skills of someone who has already occupied a certain job and task. An orientation training 
or emphasis on tasks that must be carried out (job orientation), while education is more on general development.

Training is defined by Ivancevich, cited by Edi Sutrisno, as an effort to improve the performance of the Supervisor in his current job or in another job that will be held soon.(Sutrisno 2015: 54) According to Andrew E. Sikula, quoted by Sadili Samsudin, defines education as follows, "Development is a long term educational process utilizing a systematic and organized procedure by which managerial personnel learn conceptual and theoretical knowledge for general purpose".(Samsudin 2018: 92).

Globally, the objectives of Education and Training are as follows: (1) Increased productivity in term of both quantity and quality (increasing productivity in quantity and quality). (2) Reduced accidents (reduce the number of accidents). (3) Reduced supervision. (4) Increased organizational stability and flexibility (increasing organizational stability and flexibility). (5) Heightened morale (heightens morale).(Samsudin 2018: 92)

.In the implementation of education and training programs, there are two aspects of coaching that must be carried out by school supervisors. The development of supervisory programs has not yet touched the essence of Best Practice, HOTS and adult learning.Permendikbud Number 21 of 2016 concerning Basic and Secondary Education Content Standards states explicitly that the learning outcomes in the realm of knowledge follow Bloom's Taxonomy which has been revised by Lorin Anderson and David Krathwohl consisting of the abilities: knowing (knowing-C1), understanding (knowing). C2), applying (applying-C3), analyzing (analyzing-C4), evaluating (evaluating-C5), and creating (creating-C6).(Anderson and Krathwohl 2017: 53)In accordance with Lorin Anderson and David Krathwohl's taxonomy, the dimensions of HOTS cognitive processes are analyzing, evaluating, and creating. HOTS questions generally measure the ability in the realm of analyzing (analyzing-C4), evaluating (evaluating-C5), and creating (creatingC6).(Anderson and Krathwohl 2017: 32) So to complete the aims and objectives, an evaluation must be held. Without evaluation, it will not be known 
how the condition of the evaluation object is in the design, implementation and results.

\section{B. RESEARCH, RESULTS AND DISCUSSION}

\section{1) Evaluation}

Evaluation is the determination of the value of a thing, which includes the collection of information used to decide the value of the success of a program, product, procedure, objective or benefit in the design of an alternative approach to maintain specific objectives. Bruflem argues that evaluation is "the process of delineating, obtaining, and providing useful information for judging decision alternatives." This means that evaluation is a process of describing, obtaining, and presenting useful information to formulate an alternative decision.(Worthen and Sanders 2017: 65) Meanwhile, Tague-Sutclife defines evaluation as "a systematic process of determining the extent to which instructional objectives are achieved by pupils".(Mustofa 2017: 42). Evaluation is not just assessing an activity spontaneously and incidentally, but is an activity to assess something in a planned, systematic and directed manner based on clear objectives.

The purpose of evaluation of an evaluation activity is to make decisions as stated by Tylor that the purpose of evaluation is to "develop a responsible policy regarding education", Popham stated that the purpose of evaluation is to "make better decisions". Mehrens and Lehmann expressed the opinion that the purpose of evaluation is to "help make decisions".(Mustofa 2017: 38) Even long before, Cronbach had explicitly stated that the purpose of evaluation is to "make decisions".(Sudaryono 2017: 67) The purpose of evaluation is to improve the quality of the program, provide justification or use of existing resources in activities, provide satisfaction in work and review each planned outcome. Alex Astin and Bob Panos said that the purpose of the evaluation principle is to produce information that can guide decisions regarding the adoption or modification of educational programs.(Madaus 2016: 29)

\section{2) Kirkpatrick's Evaluation}

The four-level evaluation model was first identified when Donald L. Kirkpatrick wrote four art articles entitled "Tecniques for Evaluating Training Programs" which were published in Training and Development, the journal of 
American (ASTD). These articles describe a four-level evaluation formulated by Kirkpatrick based on concepts from his dissertation in the University of Wisconsin, Madison.(Kirkpatrick 2016: 75)Kirkpatrick, DL \& Kirkpatrick JD put forward three specific reasons for evaluating training programs, namely: to justify the existence of a training budget by showing how the training program contributes to organizational goals and objectives: to determine whether a training program is continued or not; and to obtain information on how to improve future training programs(Kirkpatrick 2016: 77).

According to Donald L. Kirkpatrickin Maarif \& Kartika, there are five steps to describe each stage of Kirkpatrick's evaluation level. The five steps are a guide in evaluating each level which includes goals, data, measures, measures and results.(Maarif and Kartika 2014: 76)GOALS: Describe each measurement target at each evaluation level in order to clarify why the training evaluation needs to be carried out. DATA: Provides an explanation of what data needs to be collected and the method of collection. MEASURES: Creating a measurement guide that can be used as a guide in analyzing data at each level of training evaluation. ANALYZES: Describes the steps in analyzing each training evaluation based on the results of the data recapitulation that has been successfully obtained. RESULTS: Results and conclusions from data analysis that can be used as information for those in need.

\section{3) Best Practice}

The term best practice implies "the best experience" of the success of a person or group in carrying out tasks, including in overcoming various problems in a certain environment. Best practice is the most efficient (least effort) and effective (best outcome) way to complete a task, based on a repeatable procedure that has been shown to work for many people over a long period of time. This term is also often used to describe the process of developing a standard way of doing things that can be used by various organizations, for example in the fields of management, policy, or software systems.

The definition of best practice according to Sutikno is an idea or idea regarding a technique, method, process, activity, intensive or reward that is more 
effective in achieving extraordinary success compared to other techniques, methods, processes.(S 2016: 62)Or also defined as the most efficient (least effort) and effective (best result) way to complete a task, based on an iterative procedure (delivered in various places) by providing concrete evidence that can change the behavior of a number of people. Best practice management is to provide guidelines for organizing and managing the process, production, selection and placement at several levels, as well as the process of using the results for materials to produce new knowledge.

\section{4) HOTS}

Higher Order Thinking Skills (HOTS) or the ability to think highly is the ability of students to think in order to be able to process knowledge and ideas in a certain way so as to provide them with new knowledge and implications.(Edgar in Gunawan Adi W 2017: 92)HOTS involves critical and creative thinking so that it can generate meaningful ideas. Dependence on critical and creative thinking such as dependence on criteria and values, reasoning and emotions. HOTS is not a way of thinking by memorizing verbally only, but must arrive at the essence of what is contained. In order to be able to find meaning, a thorough way of thinking is needed either by analysis, synthesis, or by associating and then being able to draw conclusions and be able to create creative and productive ideas.(Ningsih 2018: 87)HOTS is difficult to define but easy to recognize when it occurs. HOTS involves a group of elaborative mental activities that require complex assessment and analysis. HOTS is also an endeavor that relies on self-control. The method used, the action taken, or the correct answer is not entirely determined from the previous process.

HOTS has always been the main goal of advanced educational institutions. This education is characterized by successful learning at all levels and fields. In addition, it can instill in students instructions in thinking skills and in academic disciplines. Good thinking depends on the knowledge being acquired and taught. However, the integrated ability to learn, think, and reason and the disposition in higher-order thinking do not always guarantee the acquisition of the desired knowledge.(Resnick 2013: 9)In Bloom's taxonomy, there are six levels in mapping human abilities in the cognitive domain. Of the six levels, HOTS is at 
the level of analysis, synthesis and evaluation. This taxonomy was revised by Krathwol and Anderson into analysis, evaluation, and creation.

\section{5) Adult Education}

According to Mustofa Kamil, the definition of adult education refers to the condition of adult students in terms of physical (biological), psychological, and social dimensions. A person is said to be biologically mature when he is able to reproduce. As for psychologically mature, it means that someone has responsibility for life and the decisions that are taken. Then sociologically mature, meaning that someone has been able to perform social roles that are usually applicable in society. Thus, the term adult is based on the completeness of the physical condition as well as the age and psychology, besides being able to play a role in accordance with the demands of the duties of the status one has.(Husna 2018: 88) In Islamic teachings, a person is said to be an adult when he has entered puberty, namely the age that has ended childhood and has reached adulthood in Shari'ah so that he has a determined responsibility on him to assume the obligation of syar law. 'itaclif.(Munzir 2013: 239)When entering adolescence, a person is considered to have been able to distinguish good and bad and have a broader view or thought than childhood. This period is marked by starting to experience wet dreams for men and the arrival of menstruation for women. Regarding the details of the age of men and women when they initially experienced these signs were relative, some were fast and some were slow, and generally occurred between the age range of 12-16 years. In another opinion, Elias and Sharan B. Merriam mentioned that maturity in a person includes age, psychological maturity, and social problems. Adult referred to by age, is everyone who turns 21 years old (even though they are not married). In line with this view also expressed by Hurlock, adult (adulthood) or adulthood (status in a state of maturity) refers to age 21 for early adulthood and is often counted as 7 or 8 years after a person reaches sexual maturity, or from puberty. Adults seen from the point of view of biological dimensions can also be seen from a physical point of view, where adult humans have unique characteristics such as being able to choose a life partner, ready to have a household, and reproduce (reproductive function). 
Adults based on psychological dimensions can be seen and divided into three categories, namely: early adults from 16 to 20 years of age, middle adults from 20 to 40 years, and late adults from 40 to 60 years. Hutchim and Rogers in Saraka, see the age limit around 25 to 40 years as a golden age. In this dimension, adulthood is shown in the maturity of an individual.(Saraka 2016: 82)In adult education, independence is the main benchmark in any learning model development. Therefore, the concept of learning in the context of andragogy, more specifically, has a basic core that refers to growing and developing the values of independence for each of its learners (learning citizens) . Without that purpose, any learning in the context of andragogy becomes meaningless and is the same as any other learning model. This assumption is a special limitation that is able to distinguish the concept of andragogy learning from other learning concepts(Saraka 2016: 95)

\section{6) Results of the Implementation of the Mix Method Analysis in Implementation School Supervisor Strengthening Training}

Results of the Implementation of the Education and Training it can be said that it went well and the instructors were deemed appropriate in presenting and delivering the training material. Note on the Results of Instrument 1 explains that the training facilities in the form of classroom conditions, temperature regulation in the classroom and the use of materials and tools during the training can also be said to be in accordance with the preparation. Meanwhile, the training schedule that has been designed and seen from the time adjustments with the participants, the learning conditions and the rest periods can be said to be in accordance with the implementation of the training. The assignments and exercises given to the training participants are also appropriate in the assignment and training to the participants. Likewise in case studies, solutions and discussions are appropriate for the application given to the training participants. Meanwhile, the modules given to the training participants are already in accordance with the expected training implementation from a quality perspective. Likewise, in the training material presented, it can be said that it is in accordance with the presentation to the participants. The training media used during the training and the use of various media are also in accordance with their use in presenting training materials. The 
same applies to the consumption served during the training, which is seen in terms of the quantity and quality of food, drinks and snacks by the training participants as appropriate in the presentation to the training participants. it can be said that it is according to its presentation to the participants. The training media used during the training and the use of various media are also in accordance with their use in presenting training materials. The same applies to the consumption served during the training, which is seen in terms of the quantity and quality of food, drinks and snacks by the training participants as appropriate in the presentation to the training participants. it can be said that it is according to its presentation to the participants. The training media used during the training and the use of various media are also in accordance with their use in presenting training materials. The same applies to the consumption served during the training, which is seen in terms of the quantity and quality of food, drinks and snacks by the training participants as appropriate in the presentation to the training participants.

In the result of the instrument form 2, it is applied simple random sampling technique which previously existed 1,498 data on the number of respondents, then obtained a research sample of 99 people and rounded up to 100 people as respondents. 100 of the data that has been obtained is filtering to avoid duplicate data and NULL data.(blank data). The survey carried out had 2 free response questions, namely an assessment of the supervisor's performance and special notes on the performance of the supervisors, and 6 checklist questions. The checklist question has 5 points of assessment, namely '5' for filling in strongly agree; '4' for the 'agree' statement, ' 3 ' for the 'doubtful' opinion; ' 2 ' stands for 'disagree', and ' 1 ' is 'strongly disagree'.

School Supervisors who are alumni of education and training in their area. From the results of instrument 3 forms, in total there are 19 data on the number of respondents. 4 of these data are duplicate data, and 1 data has a NULL value (blank data) in the column name, so the five data are deleted. As a result, the number of respondents data that can be processed is 14 . The survey carried out has and 1 free response question regarding the results of monitoring and evaluation of good practice by the supervisor coordinator, and 7 questions in the form of a checklist. The checklist question has 5 assessment columns, namely ' 5 ' for filling 
in strongly agree; '4' for the 'agree' statement, '3' for the 'doubtful' opinion; '2' stands for 'disagree', and ' 1 ' is 'strongly disagree'.

\section{METHODS}

This study uses a mixed method with a concurrent embedded strategy model, namely a design that uses quantitative and qualitative methods together both in data collection and data analysis carried out at one stage with a balanced weight between quantitative methods and qualitative methods.(Yusuf 2017: 23) John W. Cresswel added that this (mixed) approach is more complex than simply collecting and analyzing two types of data, but involves the functions of the two research approaches collectively so that the overall strength of this research is greater than quantitative or qualitative research.(Cresswell 2015: 47) The sample is school supervisors, amounting to 100 people. The data in this study were collected using a questionnaire and reliability testing was carried out with Cronbach Alpha.

\section{CONCLUSION}

In general, the results of the learning outcomes of the training participants have increased and the results are significant differences, it's just that when viewed from each aspect, namely the aspects of knowledge, understanding and application, that the results obtained have increased but the results of the differences and the improvements are not significant. 


\section{Bibliography}

Anderson, Lorin, and David Krathwohl. 2017. Higher Of Education. Jakarta: Grafindo Pustaka.

Cresswell, John W. 2015. Research Design Approaches to Qualitative, Quantitative and Mixed. Yogyakarta: Student Library.

Edgar in Gunawan Adi W. 2017. Genius Learning Strategy. Jakarta: Gramedia Pustaka Utama.

Husna, Kamil. 2018. Andragogy Theory. Jakarta: Gramedia Pustaka Utama.

Kirkpatrick, D. .. 2016. Effective Training, Systems, Strategies and Practices. New York: Pearson Prentice Hall.

Maarif, and Kartika. 2014. Assessment and 5-Step Evaluation. Surabaya: Insan Pustaka.

Madaus. 2016. Educational Modification. Jakarta: Mount Agung.

Munzir, Ibnu. 2013. Oral Al `Arab. Beirut: Dar al-Ahya'u al-Turasir al-`Araby.

Mustofa, Tague-Sutclife in Suryadi. 2017. Objective. Jakarta: Grafindo Pustaka. 
Ningsih, Anugerah A. 2018. High Level Thinking Ability in Islamic Religious Education Class X Students of Muhammadiyah 1 Purwokerto Vocational High School in terms of Learning Achievement ". Purwekerto.

Notoatmojo, Soekidjo. 2003. Human Resources Development. Jakarta: Rineka Cipta.

Resnick, Lauren B. 2013. Education and Learning to Think. Washington, DC: National Academic.

S, Mugenda. 2016. Human Resources. Surabaya: Light Library.

Samsudin, Sadili. 2018. Capacity Building. Jakarta: Rineka Cipta.

Saraka. 2016. Learning Model in Developing Entrepreneur Mental Attitudes. Bandung: PPS UPI.

Sudaryono. 2017. Test, Results and Score. Surabaya: Pustaka Barokah.

Sutrisno, Edi. 2015. Human Resource Management. Jakarta: Prenada Media Group.

Worthen, and Sanders. 2017. Providing Useful Information. Jakarta: Grafindo Pustaka.

Yusuf, M. 2017. Research Methods. Bogor: Ghalia Eka Pustaka. 